\title{
Effects of Tuber Depth and Soil Moisture on Infection of Potato Tubers in Soil by Phytophthora infestans
}

\author{
L. D. Porter, Department of Plant, Soil and Entomological Sciences, University of Idaho, Aberdeen Research and \\ Extension Center, Aberdeen 83210-0870; N. Dasgupta, Department of Statistics, Washington State University, \\ Pullman 99164-3144; and D. A. Johnson, Department of Plant Pathology, Washington State University, Pullman \\ 99164-6430
}

\begin{abstract}
Porter, L. D., Dasgupta, N., and Johnson, D. A. 2005. Effects of tuber depth and soil moisture on infection of potato tubers in soil by Phytophthora infestans. Plant Dis. 89:146-152.

The effects of tuber depth, soil type, and soil moisture on potato tuber infection due to Phytophthora infestans were assessed under greenhouse conditions in soil contained in large pots. Healthy tubers were used to assess infection and were either hand buried in soil at specific depths or naturally formed from potato plants growing in the soil. A spore suspension of $P$. infestans was chilled to induce zoospore formation and a suspension of resulting zoospores and sporangia were applied to the soil. Soil depth at which tubers became infected was used to determine the extent of spore movement in the soils. Tuber infection significantly decreased with increasing soil depth. Most infected tubers were found at the surface of soil; infection was rare on tubers at $5 \mathrm{~cm}$ or deeper in the soil. Amount of tuber infection varied among soil types. Significantly less tuber infection occurred in a Shano silt loam than in medium and fine sands. Only tubers on the soil surface were infected in the Shano silt loam. Depth in soil at which tubers became infected did not differ significantly among Quincy fine sand, Quincy loamy fine sand, and Quincy medium sand. Increased soil moisture did not significantly increase the soil depth at which tuber infection occurred, regardless of the soil type.
\end{abstract}

Additional keywords: irrigation, late blight

Late blight tuber rot caused by Phytophthora infestans can severely reduce potato yields in the field and cause losses in storage facilities $(26,27)$. Tuber infection occurs through buds, lenticels, and wounds $(28,53)$, but lenticel and bud resistance to infection differs among cultivars $(33,34,53)$. Tubers can become infected at low levels of inoculum (33) and as few as 2 sporangia/ml of water have been shown to be sufficient for tubers to become infected (18). Initial lesion spread usually is most apparent just under the skin of the tuber where the starchy tissue appears rustcolored to dark brown.

Several factors affect tuber infection by $P$. infestans, including foliar and tuber resistance of cultivar $(24,25,41,45)$, depth of tubers in soil $(20,28,30-32,45)$, tuber age $(5,32,33,53)$, soil type $(1-3,16,53)$, soil moisture level $(16,22,34,53)$, soil temperature (44), soil fungicides (13-15), and timing of tuber harvest $(28,38,50)$. The effects of tuber depth, soil moisture, and soil type on tuber infection have been stud-

Corresponding author: L. D. Porter

E-mail: ldporter@ uidaho.edu

Accepted for publication 19 July 2004.

DOI: 10.1094/PD-89-0146

(C) 2005 The American Phytopathological Society ied widely in the field, but conclusions have been mixed as to the efficacy of soil in protecting tubers from infection $(20,30,31)$. Some have reported that the soil depth of potato hills did not reduce the amount of tuber blight (20), whereas others concluded that soil depth over tubers did significantly suppress tuber infections (30,31). Conclusions from field studies on the movement of spores through soil may not be reliable because cracks in soil due to soil erosion, soil drying, and tuber bulking, and cavities at the side of belowground stems, facilitate deeper movement of sporangia and zoospores $(33,34)$ than when the spores are washed through an intact layer of soil.

In vitro studies provide a means to eliminate many factors that may lead to mixed results and varied conclusions from field experiments. Intact soil coverage over tubers can be accomplished in vitro, enabling soil traits that prevent, reduce, or facilitate spore movement to be more accurately assessed. Sporangia and zoospore movement through soil has been studied in vitro (16,53); however, the ability of spores to infect tubers at various depths where microorganisms and anaerobic conditions may prevail was not determined.

Reducing the risk of tuber rot due to $P$. infestans is an annual concern for potato growers in the Columbia River Basin of Washington. Understanding the effects of tuber depth, soil moisture, and soil types would assist growers in managing tuber rot due to $P$. infestans. The purposes of the present study were to (i) use an in vitro tuber infection bioassay to determine the efficacy of intact soil layers of common soil types used in potato production in the Columbia Basin of Washington in protecting buried tubers at varying depths from infection by spores of $P$. infestans and (ii) determine the influence of surface-applied irrigation water on the depth of spore movement through soil and infection of tubers at varying soil depths. Assessing the abilities of soil types to prevent or reduce below-soil tuber infection by using an in vitro study can eliminate or reduce many factors that possibly have contributed to mixed results in field studies such as soil cracking and movement of inoculum down stem tissue to underground tubers.

\section{MATERIALS AND METHODS}

Sporangia production. Isolates 1799 , 701 , and 502 of $P$. infestans were used in these studies. All belong to the US- 8 clonal lineage (21). Isolates 1799 and 502 were collected from potato foliage from central Washington in 1999 and 2002, respectively. Isolate 701 was collected from potato foliage from southeastern Washington in 2001. Isolates were maintained and increased on excised leaflets of potato cvs. Ranger Russet or Russet Burbank. To increase inoculum, sporangia from lesions on leaflets were rinsed with distilled water into a beaker to a concentration of 50,000 to 65,000 sporangia/ml. A hemacytometer was used to calculate sporangia concentrations for all experiments. The spore suspension was incubated for $2 \mathrm{~h}$ at $4^{\circ} \mathrm{C}$ to induce zoospore formation. A $1-\mathrm{cm}^{2}$ Whatman no. 2 filter paper square then was submerged in the suspension for approximately $1 \mathrm{~s}$ and placed in the center of the adaxial surface of a freshly cut leaflet. Approximately 100 to 125 leaflets for each experiment were placed with the adaxial surface downward on a fiberglass screen over moistened paper towels in 35-by-25by-12.5-cm plastic containers. Leaflets were incubated at $15^{\circ} \mathrm{C}$ for 6 days with an 18-h photoperiod. Sporangia that formed from lesions were rinsed from leaflets with distilled water into a 4-liter flask. Sporangia concentrations varied among experiments and will be given for each experi- 
ment. The sporangia suspension then was chilled for $2 \mathrm{~h}$ at $4^{\circ} \mathrm{C}$ to induce zoospore formation. A $50-\mu 1$ drop of the spore suspension was observed after the chill period under a compound microscope to confirm zoospore formation. The spore suspension was taken immediately to the study site with a transport time of $3 \mathrm{~min}$.

Soil types. Soil types used in the experiments were classified as a Quincy medium sand (36), Quincy fine sand (19), Quincy loamy fine sand (42), Shano silt loam (36), and Garden Rite potting soil (Soil Conditioners, Zillah, WA). The potting soil ( $\mathrm{pH}$ 5.25) was composed of $10.97 \mathrm{~m}^{2}$ of peat moss, $6.9 \mathrm{~m}^{2}$ of pumice, $9.1 \mathrm{~kg}$ of calcium nitrate, $27.3 \mathrm{~kg}$ of Ag lime (J. A. Jack \& Sons Inc., Seattle, WA), $9.1 \mathrm{~kg}$ of treble phosphate, $0.45 \mathrm{~kg}$ of gypsum, and $6.8 \mathrm{~kg}$ of K-Mag (IMC USA, Inc., Mulberry, FL). for every $18.3 \mathrm{~m}^{2}$ of mix. The Quincy medium sand, Quincy fine sand, Quincy loamy fine sand, and Shano silt loam were $\mathrm{pH} 6.6$ to $7.3,6.6$ to $8.4,7.4$ to 8.4 , and 7.4 to 9.0 , respectively $(19,36,42)$. The moist bulk densities of the Quincy medium sand, Quincy fine sand, Quincy loamy fine sand, and Shano silt loam were 1.5 to $1.70,1.45$ to $1.60,1.45$ to 1.65 , and 1.15 to 1.45 $\mathrm{g} / \mathrm{ml}$, respectively (47-49).

Soil preparation. Soils were collected from native sagebrush ground. Soils were air dried and sifted through a screen containing $0.5-\mathrm{cm}^{2}$ openings to remove rocks and root debris. Pots measuring $35 \mathrm{~cm}$ in diameter by $25 \mathrm{~cm}$ in depth were filled with gravel to a depth of $5 \mathrm{~cm}$. The gravel measured $0.63 \mathrm{~cm}$ in diameter. Soil was placed on top of the gravel to a depth of 19 $\mathrm{cm}$ using a hand trowel. Tubers used in experiments were uniform in size or were uniform in size within replicates.

Tuber placement in pots. Certified healthy seed tubers of cv. Ranger Russet were used as a bioassay to assess infectivity of inoculum and were maintained at $4^{\circ} \mathrm{C}$ until use. Tubers either were buried in pots at varying depths or were the progeny tubers grown from a single seed tuber planted 7.5 to $10 \mathrm{~cm}$ deep in the soil. Tubers buried at specific depths were arranged so that the bud and stolon ends of a tuber were at the same soil depth and tubers within a pot were not directly above one another. Tuber depth was measured from the soil surface to the uppermost part of a buried tuber. Tubers were placed at least $2.5 \mathrm{~cm}$ from the edge of the pot. Depth of tubers that became infected was used to indicate depth of viable spore movement.

Water application. Adjustable water drippers (model B02; Dig Corporation, San Marcos, CA) were held in place with stakes over the center of each pot. Stakes holding the drippers were angled toward the edge of the pots and away from the buried tubers. Drippers were approximately 2.0 to $2.5 \mathrm{~cm}$ above the soil surface. Water was emitted at a rate of $14 \mathrm{ml} / \mathrm{s}$ in a circular pattern approximately 23 to 24 $\mathrm{cm}$ in diameter. Soil in each pot was prewetted with approximately $70 \mathrm{ml}$ of water immediately before the soil was infested with a spore suspension, except in one experiment (experiment B), as noted. The irrigation system was used to apply the water before each soil infestation. Water volumes varied depending on the experiment.

Application of inoculum to soil. A spore suspension $(100 \mathrm{ml})$ containing sporangia and zoospores of $P$. infestans was applied to each pot using a graduated cylinder when greenhouse temperatures were between 14 and $19^{\circ} \mathrm{C}$. Inoculum was applied to the soil at night, when cooler temperatures prevailed, to maximize survival, activity, and infection by spores $(12,44,53)$. The inoculum either formed a band approximately $5 \mathrm{~cm}$ wide on the soil surface over buried tubers or was applied uniformly over the entire soil surface when progeny tubers had been produced from a mother plant. Application of inoculum was completed for each experiment within 25 to $30 \mathrm{~min}$. Greenhouse temperatures were recorded during application of inoculum.

Assessment of tuber infection. Tubers were harvested and assessed for rot 10 to 18 days after application of inoculum. Harvested tubers were cut perpendicular to the bud and stolon ends at approximately $0.5 \mathrm{~cm}$ intervals to form circular discs and assessed for late blight symptoms. Tuber discs were removed from tubers with late blight symptoms and placed on fiberglass screens over moistened filter paper in 9$\mathrm{cm}$-diameter by 1.5 -cm-deep petri dishes. Petri dishes were arranged randomly in an 18.5-liter plastic container with moistened paper towels in the bottom and incubated at $15^{\circ} \mathrm{C}$ with an 18 -h photoperiod for 24 to 48 h. Tuber discs then were observed under a dissecting microscope for sporulation of $P$. infestans.

Air temperature and soil water potential. Atmospheric temperature was recorded every 15 to 30 min using a model 450 Watch Dog Data Logger (Spectrum Technologies, Inc. Plainfield, IL). Watermark water potential sensors (Spectrum Technologies Inc., Plainsfield, IL) were buried just beneath the soil surface and extended $5 \mathrm{~cm}$ into the potted soil. Sensors were placed either in the center of each pot (experiments $\mathrm{A}$ and $\mathrm{C}$ ) or $5 \mathrm{~cm}$ from the side (experiment $\mathrm{B}$ ) to avoid disrupting the soil directly above tubers located below the soil surface. Water potential sensors were buried in the pots immediately before application of inoculum. Water potential was determined 10 to $15 \mathrm{~min}$ after irrigation water was applied to pots and again $24 \mathrm{~h}$ post irrigation. The mean and range of water potential for treatments were calculated from replicate values.

Effects of soil type and tuber depth on tuber infection. The effects of soil type and tuber depth on tuber infection were assessed in two experiments. Both experi- ments were repeated. Spore movement of $P$. infestans was determined based on soil depths at which tubers became infected. Soil treatments were arranged in a Latin Square design with five replicates. In the first experiment, tubers were buried at soil depths of 0,2 , and $4 \mathrm{~cm}$ in each pot (experiment A). Each depth contained two tubers for a total of six tubers per pot. Tubers used ranged from 74 to $299 \mathrm{~g}$. Soil in each pot was infested with $1.2 \times 10^{6}$ sporangia. Soil in each pot was wetted with $800 \mathrm{ml}$ of water, which simulated irrigation or rainfall of $0.83 \mathrm{~cm}$. Soil was wetted immediately after application of inoculum and $24 \mathrm{~h}$ later with an additional $800 \mathrm{ml}$.

In the second experiment, progeny tubers were grown directly in the soil (experiment B). Whole seed tubers weighing between 51 to $88 \mathrm{~g}$ for the first trial and 131 to $191 \mathrm{~g}$ for the second trial were planted. Plants were fertilized every 2 weeks with $500 \mathrm{ml}$ of Miracle-Gro (15:30:15 N-P-K; Scotts Miracle-Gro Products, Inc., Marysville, $\mathrm{OH}$ ) at a concentration of $4 \mathrm{~g}$ per 3.78 liter. Stems were cut approximately $3 \mathrm{~mm}$ above the soil line and removed from pots 130 and 140 days after planting for the first and second trials, respectively. Two Watermark sensors were buried in pots to measure water potential. The sensors were placed directly on top of each other, with the top sensor just under the soil surface. Soil in each pot was prewetted with $140 \mathrm{ml}$ of water before application of inoculum to the soil. Soil was infested with $5.0 \times 10^{5}$ sporangia/pot 3 weeks after stems were cut. Immediately after application of inoculum, 2.5 liters of water was applied to the soil surface which simulated irrigation or rainfall of $2.6 \mathrm{~cm}$. Tubers were harvested after excavating a columnar cavity near the side wall of each pot, from the soil surface to the gravel bottom. The wet soil walls of the cavity maintained composure and did not crumble. This process allowed soil to be carefully shaved from the walls of the cavity with a thin, rectangular-shaped piece of plastic, 3 by $30 \mathrm{~cm}$ in size, until a tuber was contacted. The distance from the top of the soil to the uppermost part of the tuber then was measured. Each tuber obtained in this fashion then was assessed for infection by cutting the tubers as previously described.

Effects of soil type, tuber depth, and soil moisture on infection. The effects of soil type, tuber depth, and soil moisture were assessed in two experiments. In the first experiment, soil type and water volumes added to the soil surface were arranged in a 4-by-3 factorial design for a total of 12 treatments, with two replicates for each treatment (experiment C). All soil types previously mentioned were tested in experiment $\mathrm{C}$ except the Quincy fine sand. The Quincy fine sand was not used in this test because one of the other soils being tested was a fine sand and there was a need 
to increase the number of replicates for different water volumes. The water volumes added to the soil surface were 1, 2.5, and 4.5 liters, which simulated irrigation or rainfall of $1.04,2.6$, and $4.6 \mathrm{~cm}$. Treatments were arranged in a completely randomized design. Tubers were buried at soil depths of 0,5 , and $13 \mathrm{~cm}$ in each pot. Each depth contained three tubers for a total of nine tubers per pot. Soil was infested with $5.0 \times 10^{4}$ sporangia/pot and then, $24 \mathrm{~h}$ later, with $8.13 \times 10^{5}$ sporangia/pot. Water volumes were applied to the soil after each application of inoculum. Tubers were harvested 18 days after the second application of inoculum and percent incidence of rot due to $P$. infestans was recorded. Water potential readings were not taken for this experiment because, in previous experiments, all soils were saturated when 1, 2.5, and 4.5 liters of water were applied to pots. This experiment was repeated.

In the second experiment, tuber infection was assessed at 0,8 , and $17 \mathrm{~cm}$ in Quincy medium sand (experiment D). Five watering treatments were arranged in a Latin Square design with five replicates. Three tubers were buried at each depth for a total of nine tubers per pot. Soil in pots was infested with $2.83 \times 10^{5}$ sporangia and then, 4 days later, with $7.91 \times 10^{5}$ sporangia. Water was applied to the surface of the soil in each pot at one of five water volumes, 200, 400, 600, 800, and 1,000 ml, which simulated irrigation or rainfall of $0.21,0.42,0.62,0.83$, and $1.04 \mathrm{~cm}$, respectively. Water volumes were applied to the soil after each application of inoculum. Tubers were collected 10 days after the second application of inoculum and incidence of infection was recorded.
Statistics. The response data for tuber infection were binary: infection or no infection. Therefore, data for incidence of tuber infection were analyzed using techniques applicable to binary data: logistic regression $(23,43)$, test of pair-wise differences of two proportions with multiplicity adjusted Bonferroni procedure (29), and goodness of fit tests (23). Analysis was performed using MINITAB (release 12.1; Minitab Inc., University Park, PA) and SAS (SAS Institute, Cary, NC). Binary logistic regression was used to analyze incidence data when data were continuous. Binary logistic regression was used in experiment $\mathrm{C}$, because there was overlap (43) in the data for the explanatory variables. Data from experiments A, B, and D were separated or quasi-separated (43). Initially for these experiments (A, B, and D) a $\chi^{2}$ test of association was done to look for associations between the response and the explanatory variables and followed by a test of pairwise differences of two proportions with a Bonferroni adjustment. The results of the preliminary $\chi^{2}$ tests are not reported because they are similar to the results obtained through the test of proportions. Data for levels of sporulation on tuber discs were analyzed by analysis of variance using a Proc GLM procedure in SAS.

\section{RESULTS}

Air temperature and soil water potential. Air temperatures during application of inoculum were between 14 and $19^{\circ} \mathrm{C}$ for all experiments. Air temperatures and soil water potentials were 14 to $28^{\circ} \mathrm{C}$ and 0 to 28 centibars (Tables 1 and 2), respectively, during the first $24 \mathrm{~h}$ post application of inoculum when an irrigation event immediately followed. Water potential values between 0 and 10 centibars represented saturated soil.

Table 2. Means and ranges of water potentials during the $24 \mathrm{~h}$ post-inoculation period when $P$. infestans was applied to the soil surface and one of five water volumes was applied to the soil surface $(\text { experiment } \mathrm{D})^{\mathrm{x}}$

\begin{tabular}{llllll}
\hline & \multicolumn{5}{c}{${\text { Water volume }(\mathbf{m l})^{\mathbf{y}}}^{\mathbf{y}}$} \\
\cline { 2 - 6 } Water potential (centibars) & \multicolumn{1}{c}{$\mathbf{2 0 0}$} & $\mathbf{4 0 0}$ & $\mathbf{6 0 0}$ & $\mathbf{8 0 0}$ & $\mathbf{1 , 0 0 0}$ \\
\hline Application 1 & $20 \pm 1.4$ & $20 \pm 2.8$ & $19 \pm 2.1$ & $16 \pm 0.7$ & $27 \pm .1$ \\
$\quad$ Mean & $19-21$ & $18-21$ & $20-17$ & $15-16$ & $25-28$ \\
$\quad$ Range & & & & & \\
Application 2 & $78 \pm 12$ & $43 \pm 2.8$ & $14 \pm 1.4$ & $13 \pm 0.7$ & $41 \pm 8.5$ \\
$\quad$ Mean & $69-86$ & $41-45$ & $13-15$ & $12-13$ & $35-47$ \\
Range &
\end{tabular}

${ }^{\mathrm{x}}$ Range is defined as the highest and lowest water potential reading measured by any sensor for a given soil type during the $24 \mathrm{~h}$ following application of inoculum to the soil. Quincy medium sand was used for this experiment.

${ }^{y}$ Application 1 = first application of inoculum to the soil and application $2=$ second application of inoculum, 4 days after first application to soil.

${ }^{\mathrm{z}}$ Volumes \pm mean standard error.

Table 1. Means and ranges for water potentials of five soil types during the 24-h post-inoculation period when Phytophthora infestans was applied to the soil surface in two experiments (experiments A and B) ${ }^{\mathrm{x}}$

\begin{tabular}{|c|c|c|c|c|c|}
\hline \multirow[b]{2}{*}{ Water potential (centibars) ${ }^{\mathrm{z}}$} & \multicolumn{5}{|c|}{ Soil type $^{y}$} \\
\hline & Silt loam & LF sand & M sand & F sand & Soil \\
\hline \multicolumn{6}{|l|}{ Experiment A } \\
\hline \multicolumn{6}{|l|}{ Trial 1} \\
\hline Mean & $23 \pm 3$ & $11 \pm 2$ & $4 \pm \pm 2$ & $6 \pm 2$ & $6 \pm 6$ \\
\hline Range & $19-25$ & $7-13$ & $2-5$ & $4-9$ & $2-14$ \\
\hline \multicolumn{6}{|l|}{ Trial 2} \\
\hline Mean & $19 \pm 6$ & $9 \pm 4$ & $1 \pm 2$ & $10 \pm 4$ & $2 \pm 3$ \\
\hline Range & $12-27$ & $4-15$ & $0-4$ & $3-15$ & $0-10$ \\
\hline \multicolumn{6}{|l|}{ Experiment B } \\
\hline \multicolumn{6}{|l|}{ Trial 1 (sensor at surface) } \\
\hline Mean & $21 \pm 13$ & $10 \pm 2.1$ & $4 \pm 2.1$ & $3 \pm 1.4$ & $7 \pm 4.9$ \\
\hline Range & $11-30$ & $8-11$ & $2-5$ & $2-4$ & $3-10$ \\
\hline \multicolumn{6}{|l|}{ Trial 1 (sensor at $7 \mathrm{~cm}$ ) } \\
\hline Mean & $18 \pm 6.4$ & $7 \pm 4.9$ & $7 \pm 5.7$ & $0 \pm 0$ & $3 \pm 1.4$ \\
\hline Range & $13-22$ & $3-10$ & $3-11$ & $0-0$ & $2-4$ \\
\hline \multicolumn{6}{|l|}{ Trial 2 (sensor at surface) } \\
\hline Mean & $17 \pm 8.5$ & $0 \pm 0$ & $10 \pm 0$ & $4 \pm 1.4$ & $4 \pm 1.4$ \\
\hline Range & $11-23$ & $0-0$ & $0-10$ & $3-5$ & $3-5$ \\
\hline \multicolumn{6}{|l|}{ Trial 2 (sensor at $7 \mathrm{~cm}$ ) } \\
\hline Mean & $8 \pm 9.9$ & $4 \pm 0.7$ & $0 \pm 0$ & $1.5 \pm 0.7$ & $0 \pm 0$ \\
\hline Range & $1-15$ & $3-4$ & $0-0$ & $1-2$ & $0-0$ \\
\hline
\end{tabular}

${ }^{\mathrm{x}}$ Range is defined as the highest and lowest water potential reading measured by any sensor for a given soil type during the $24 \mathrm{~h}$ following application of inoculum to the soil.

y Silt loam = Shano silt loam, LF sand = Quincy loamy fine sand, M sand = Quincy medium sand, F sand = Quincy fine sand, and Soil = potting soil (peat moss and pumice); \pm mean standard error.

z Sensors are watermark water potential sensors. 
Effects of soil type and tuber depth on tuber infection. In both trials where tubers were buried to assess spore movement, the total percentage of incidence of tuber infection in the potting soil was significantly greater than in the other soil types $(P<$ 0.05 , experiment A; Table 3 ). There were no significant differences in incidence of tuber infection among Quincy medium sand, Quincy loamy fine sand, and Quincy fine sand soils $(P>0.05$; Table 3$)$. Incidence of infected tubers was significantly less in the Shano silt loam compared with the other soil types. Incidence of infected tubers decreased with increasing soil depth for all soil types (Table 3).

When progeny tubers were used as a bioassay for movement of spores, the combined incidence of tuber infection in the five soil types was 13 and $27 \%$ for the first and second trials, respectively (experiment B; Table 4). Incidence of tuber infection at the soil surface was near $50 \%$ for both trials; 23 of the 51 tubers located $2 \mathrm{~mm}$ or less from the soil surface in the first trial and 106 of 217 tubers in the second trial were infected (Table 4). The greatest tuber depth at which infection was found was 67 $\mathrm{mm}$ in a Quincy medium sand in the first trial (Table 4) and $102 \mathrm{~mm}$ in the potting soil in the second trial (Table 4).

Effects of soil type, tuber depth, and soil moisture on tuber infection. Incidence of tuber infection when 1, 2.5, and 4.5 liters of water was applied to the soil surface in pots was 33,33 and $29 \%$, respectively (experiment C). Amount of tuber infection did not vary significantly with increasing volumes of water applied to the soil $(P>0.05)$. The amount of tuber infection significantly decreased with increasing soil depth $(P>0.05)$. Incidence of tuber infection at the soil surface and the 5- and 13-cm soil depths, for all treatments combined, was 65,25 , and $6 \%$, respectively. Results were similar when the experiment was repeated and, therefore, are not shown.

Tuber infection was significantly greater in the potting soil than in all other soils and incidence of infection did not vary for the Quincy loamy fine sand and Quincy medium sand $(P<0.05$; Table 5). Incidence of tuber infection was significantly less in the Shano silt loam than in the potting soil, Quincy loamy fine sand, and Quincy medium sand $(P<0.05$; Table 5$)$. Only tubers exposed at the surface in the Shano silt loam became infected.

Negative interactions occurred between soil type and tuber depth for incidence of tuber infection. Tuber infection was significantly greater at the $5-\mathrm{cm}$ soil depth in the potting soil than in the Quincy loamy sand, Quincy medium sand, and Shano silt loam soils $(P<0.05$; Table 5$)$. Only the potting soil (three tubers) and Quincy loamy fine sand (one tuber) had tubers infected at a soil depth of $13 \mathrm{~cm}$, but the difference was not significant.

Of the tubers at the soil surface, $76 \%$ were infected when water treatments were combined in the second experiment (experiment D). Tubers did not become infected at soil depths of 8 and $17 \mathrm{~cm}$. Incidence of tuber infection when water volumes of $200,600,400,800$, and 1,000 $\mathrm{ml}$ of water were applied to the soil surface was $27,29,27,22$, and 22, respectively, and was not significantly different $(P>0.05)$.

\section{DISCUSSION}

The soil types tested in the present study comprise some of the most common soil types used for potato production in the Columbia Basin of Washington. Soil types were taken from Grant, Benton, and Adams Counties, which are ranked first, third, and fourth, respectively, in acres of potato harvested in the state of Washington (9). The Shano silt loam and Quincy fine sand are the most common soil types found in Adams and Grant Counties, respectively (19,36). Quincy fine sand and Quincy loamy fine sand are the second and third most common soil types found in Benton county (42). The Quincy medium sand was incorporated in the study because it represented an additional unique soil type.

Regardless of soil type in the present studies, tuber infection by $P$. infestans was rare below a depth of $5 \mathrm{~cm}$ in intact soil (Tables 4 and 5). However, the extent of spore movement varied depending on the soil type. Spore movement through soil is dependent on pore size distribution and size of water-filled pores within the soil $(10,11)$, which in turn are determined by water potential and soil structure $(10,11)$. The pore size in soil decreases as the moisture level increases, but increased soil moisture provides a continuous water medium which benefits the movement of sporangia and zoospores through soil. The pore size of a silt soil, very fine sand, fine sand, and medium sand previously were reported to range from 2 to 50,50 to 100 , 100 to 250 , and 250 to $500 \mu \mathrm{m}$, respectively (35). Approximately $70 \%$ of the pore sizes in the silt soil were $20 \mu \mathrm{m}$ in diameter or less, and $30 \%$ were $10 \mu \mathrm{m}$ in diameter or less (35). Sporangia of $P$. infestans are 29 to $36 \mu \mathrm{m}$ long by 19 to $22 \mu \mathrm{m}$ wide (17). Zoospores of $P$. infestans are smaller, 11 to $15 \mu \mathrm{m}$ long by 7.5 to $8.5 \mu \mathrm{m}$ wide (4). Water-filled soil pores of 40 to $60 \mu \mathrm{m}$ in diameter are required to facilitate active or passive movement of zoospores through soil (51). The pore sizes of the Shano silt loam likely range from 2 to $50 \mu \mathrm{m}$, with a majority of the pore sizes between 10 and $20 \mu \mathrm{m}$, based on a previous silt loam soil type (35). This may contribute to why tubers were not infected when covered by $2 \mathrm{~cm}$ or more of Shano silt loam soil because the pore sizes could have been small enough to prevent sporangia and zoospore movement through the soil. All the soil types, except the Shano silt loam, have sufficient pore size to facilitate the passage of zoospores and sporangia of $P$. infestans. The smaller pore size in the silt soils also may lead to more impact events by zoospores that could cause them to encyst sooner than in other soil types with greater pore sizes (8). In potato production areas with silty soils, prevention of tuber infection by $P$. infestans needs to focus on cultural practices that will maintain intact soil coverage on the tubers; because sporangia and zoospores may not be easily washed through intact silt soils, the avenue of infection for tubers in potato fields must be cracks or cavities formed in the soil.

When tubers that had an intact Shano silt loam soil coverage were compared

Table 3. Incidence of potato tuber infection at three soil depths when sporangia of Phytophthora infestans were applied to the soil surface of five soil types in greenhouse pots $(n=10 \text {; experiment } \mathrm{A})^{\mathrm{y}}$

\begin{tabular}{|c|c|c|c|c|c|c|c|c|}
\hline \multirow[b]{3}{*}{ Soil type } & \multicolumn{8}{|c|}{ Incidence of infection $(\%)^{\mathrm{z}}$} \\
\hline & \multicolumn{4}{|c|}{ Trial 1} & \multicolumn{4}{|c|}{ Trial 2} \\
\hline & Surface & $2 \mathrm{~cm}$ & $4 \mathrm{~cm}$ & Total $(\%)$ & Surface & $2 \mathrm{~cm}$ & $4 \mathrm{~cm}$ & Total $(\%)$ \\
\hline Potting soil & $100 \mathrm{a}$ & $80 \mathrm{a}$ & $60 \mathrm{a}$ & $80 \mathrm{~A}$ & $100 \mathrm{a}$ & $100 \mathrm{a}$ & $60 \mathrm{a}$ & $87 \mathrm{~A}$ \\
\hline Quincy medium sand & $100 \mathrm{a}$ & $20 \mathrm{bc}$ & $20 \mathrm{c}$ & $47 \mathrm{~B}$ & $60 \mathrm{a}$ & $20 \mathrm{ab}$ & $0 \mathrm{~b}$ & $27 \mathrm{~B}$ \\
\hline Quincy fine sand & $90 \mathrm{a}$ & $50 \mathrm{a}$ & $0.0 \mathrm{~b}$ & $47 \mathrm{~B}$ & $50 \mathrm{a}$ & $30 \mathrm{ab}$ & $0 \mathrm{~b}$ & $27 \mathrm{~B}$ \\
\hline Quincy loamy fine sand & $100 \mathrm{a}$ & $40 \mathrm{~b}$ & $10 \mathrm{~b}$ & $50 \mathrm{~B}$ & $40 \mathrm{a}$ & $0 \mathrm{a}$ & $0 \mathrm{a}$ & $13 \mathrm{~B}$ \\
\hline Shano silt loam & $80 \mathrm{a}$ & $0.0 \mathrm{~b}$ & $0.0 \mathrm{~b}$ & $27 \mathrm{C}$ & $10 \mathrm{a}$ & $0 \mathrm{a}$ & $0 \mathrm{a}$ & $3.0 \mathrm{C}$ \\
\hline
\end{tabular}

y Approximately $1 \times 10^{6}$ sporangia that had been chilled for $2 \mathrm{~h}$ at $4^{\circ} \mathrm{C}$ were applied to the soil surface in each pot in $100 \mathrm{ml}$ of water. The soil in each pot received $800 \mathrm{ml}$ of water, which was equivalent to $0.83 \mathrm{~cm}$ of rain or irrigation water. Pots were $35 \mathrm{~cm}$ in diameter by $25 \mathrm{~cm}$ deep. Potato tubers of cv. Ranger Russet were used.

${ }^{\mathrm{z}}$ Lowercase letters within a row represent significant differences between soil depths for a given soil type. Uppercase letters within a column represent significant differences between the soil types in percent total incidence. Significant differences for both upper- and lowercase letters were determined using a series of pairwise differences by tests of two proportions with an adjusted Bonferroni procedure $(P<0.05)$. 
with tubers that were naturally grown in Shano silt loam soil, the only tubers infected in the intact Shano silt loam were those exposed at the surface. Tubers buried at a depth of $2 \mathrm{~cm}$ or greater under an intact Shano silt loam soil were protected from infection ( 0 of 88 tubers infected). However, when tubers were produced naturally in Shano silt loam, there were 8 of 73 infected tubers at a depth of $2 \mathrm{~cm}$ or greater (Table 4). Cracks developed in the Shano silt loam when tubers were produced naturally due to tuber bulking near the soil surface and soil drying. Also, when stems dried due to vine kill, there was space created between the stem and the soil because the stem diameter was reduced in size due to dehydration. Conse- quently, when the spore suspension was applied to the soil, there was greater opportunity for spores to be washed down soil fissures and through spaces created by the desiccation of the potato stems. This may account for the occurrence of infected tubers in the Shano silt loam at soil depths greater than $2 \mathrm{~cm}$ when tubers were grown naturally, whereas no tuber infection occurred at these depths when tubers were buried under intact soil. Depth of tuber infection recorded in previous field studies $(20,31,34,40)$ may not be a true indication of the ability of spores to wash through and infect tubers in the soil. Soil over potato tubers in the field may crack or develop fissures due to soil erosion, soil drying, and tuber bulking. Water travels the

Table 4. Potato tuber infection by Phytophthora infestans at different soil depths in five soil types $(\text { experiment B })^{\mathrm{w}}$

\begin{tabular}{|c|c|c|c|c|}
\hline Soil, depth range $(\mathrm{mm})$ & $\begin{array}{l}\text { No. tubers } \\
\text { T1/T2x }\end{array}$ & $\begin{array}{c}\text { Infected T1/T2 } \\
(\%)^{\mathrm{y}}\end{array}$ & $\begin{array}{c}\text { Depth T1 } \\
(\mathbf{m m})^{\mathrm{z}}\end{array}$ & $\begin{array}{c}\text { Depth T2 } \\
(\mathbf{m m})^{\mathrm{z}}\end{array}$ \\
\hline \multicolumn{5}{|l|}{ Potting mix } \\
\hline $0-2$ & $4 / 12$ & $0 / 50$ & $\mathrm{~N}$ & $0(5)$ \\
\hline $2.1-10$ & 9/9 & $0 / 0$ & $\mathrm{~N}$ & 1 \\
\hline \multirow[t]{4}{*}{$>10$} & $91 / 109$ & $1 / 5$ & 15 & $\mathrm{~N}$ \\
\hline & $\ldots$ & $\ldots$ & $\mathrm{N}$ & $20(3)$ \\
\hline & $\ldots$ & $\ldots$ & $\mathrm{N}$ & 27 \\
\hline & $\ldots$ & $\ldots$ & $\mathrm{N}$ & 102 \\
\hline Quincy medium sand & $\ldots$ & $\ldots$ & $0(6)$ & $0(3)$ \\
\hline $0-2$ & $15 / 17$ & $60 / 24$ & 1 & $\mathrm{~N}$ \\
\hline $2.1-10$ & $2 / 6$ & $0 / 17$ & $2(2)$ & 2 \\
\hline \multirow{6}{*}{$>10$} & $27 / 23$ & $11 / 9$ & $\mathrm{~N}$ & 3 \\
\hline & $\ldots$ & $\ldots$ & $\mathrm{N}$ & 15 \\
\hline & $\ldots$ & $\ldots$ & 20 & $\mathrm{~N}$ \\
\hline & $\ldots$ & $\ldots$ & $\mathrm{N}$ & 25 \\
\hline & $\ldots$ & $\ldots$ & 38 & $\mathrm{~N}$ \\
\hline & $\ldots$ & $\ldots$ & 67 & $\mathrm{~N}$ \\
\hline Quincy fine sand & $\ldots$ & $\ldots$ & $\mathrm{N}$ & $0(49)$ \\
\hline $0-2$ & $4 / 88$ & $0 / 61$ & $\mathrm{~N}$ & $1(3)$ \\
\hline $2.1-10$ & $1 / 8$ & $0 / 13$ & $\mathrm{~N}$ & $2(2)$ \\
\hline \multirow[t]{5}{*}{$>10$} & $6 / 27$ & $0 / 15$ & $\mathrm{~N}$ & 10 \\
\hline & $\ldots$ & $\mathrm{N}$ & $\mathrm{N}$ & 20 \\
\hline & $\ldots$ & $\mathrm{N}$ & $\mathrm{N}$ & 30 \\
\hline & $\ldots$ & $\mathrm{N}$ & $\mathrm{N}$ & 40 \\
\hline & $\ldots$ & $\mathrm{N}$ & $\mathrm{N}$ & 42 \\
\hline Quincy loamy fine sand & $\ldots$ & $\ldots$ & $0(7)$ & $0(4)$ \\
\hline $0-2$ & $18 / 41$ & $44 / 15$ & 1 & $1(2)$ \\
\hline $2.1-10$ & $7 / 3$ & $0 / 33$ & $\mathrm{~N}$ & 4 \\
\hline$>10$ & $13 / 38$ & $0 / 3$ & $\mathrm{~N}$ & 40 \\
\hline Shano silt loam & $\ldots$ & $\ldots$ & $0(5)$ & $0(31)$ \\
\hline $0-2$ & $10 / 59$ & $60 / 61$ & 1 & $1(4)$ \\
\hline $2.1-10$ & $4 / 12$ & $25 / 42$ & $\mathrm{~N}$ & 2 \\
\hline \multirow[t]{9}{*}{$>10$} & $40 / 36$ & $13 / 11$ & $\mathrm{~N}$ & $3(2)$ \\
\hline & $\ldots$ & $\ldots$ & 5 & 5 \\
\hline & $\ldots$ & $\ldots$ & $\mathrm{N}$ & $10(2)$ \\
\hline & $\ldots$ & $\ldots$ & 16 & $\mathrm{~N}$ \\
\hline & $\ldots$ & $\ldots$ & $\mathrm{N}$ & $20(2)$ \\
\hline & $\ldots$ & $\ldots$ & $25(2)$ & 25 \\
\hline & $\ldots$ & $\ldots$ & 31 & $\mathrm{~N}$ \\
\hline & $\ldots$ & $\ldots$ & 35 & $\mathrm{~N}$ \\
\hline & $\ldots$ & $\ldots$ & $\mathrm{N}$ & 60 \\
\hline
\end{tabular}

${ }^{\text {w}}$ Soil was inoculated under greenhouse conditions with $5.0 \times 10^{5}$ sporangia/pot in $100 \mathrm{ml}$ of water that had been chilled at $3.3^{\circ} \mathrm{C}$ for $2 \mathrm{~h}$ to induce zoospore formation. Soil was irrigated with 2.5 liters of water after inoculation, which was equivalent to $2.5 \mathrm{~cm}$ of rainfall or irrigation water. Pots were 35 $\mathrm{cm}$ in diameter by $25 \mathrm{~cm}$ deep. Potato tubers of $\mathrm{cv}$. Ranger Russet were used. $\mathrm{T} 1=$ trial 1 and $\mathrm{T} 2=$ trial 2.

${ }^{x}$ Number of tubers for a given depth range.

y Percentage of infected tubers for a given depth range.

${ }^{\mathrm{z}}$ Specific depth of infected tubers for a given soil type; $\mathrm{N}=$ no infected tubers at that depth for that trial, $0=$ tuber was exposed at the surface, and number in parentheses $=$ the total number of infected tubers found at that depth for the trial. If no parentheses are present, then only a single tuber was infected at the given depth. path of least resistance when moving through soil (37). Therefore, water would be more likely to move through cracks and openings in the soil than to diffuse through intact soil. Spores surviving at the surface could be carried easily through the spaces formed by the stem and soil cracks. Macropore spaces also could be formed by dead roots and burrowing organisms (10). Cavities at the side of the stems also can facilitate sporangia or zoospore washing to greater depths than if the spores had to pass through intact soil $(33,34)$.

Tuber infection decreased with increasing soil depth in all soils tested. Concentrations of sporangia and zoospores are reduced at greater soil depths due to the filtering capabilities of the soil type (16). Variation in filtering capabilities of soil types helps explain the lower incidence of infection at greater soil depths because of a fewer number of spores. The pore size of all the sandy soils are large enough to allow the passage of sporangia and zoospores; therefore, other factors may be involved in limiting tuber infection at soil depths greater than $5 \mathrm{~cm}$ such as oxygen levels $(11,52,53)$, microorganisms $(11,39)$, negative geotaxic tendencies of zoospores $(7,8)$, and tendency of zoospores to encyst on impact with foreign objects (8).

Available oxygen decreases as soil depth increases, especially in saturated soils $(6,11)$. Lack of available oxygen also may explain low tuber infection at greater soil depths. Low levels or absence of oxygen inhibits direct germination of sporangia of $P$. infestans $(52,53)$. Sporangia require the presence of oxygen to germinate directly not only in $P$. infestans, but also in $P$. palmivora and $P$. parasitica (52). In addition, spores of Albugo candida, Plasmopara viticola, and Sclerospora gramnicola require oxygen to germinate directly (52). Soil populations of microorganisms also compete for available oxygen and have been implicated in preventing sporangia of Phytophthora infestans from germinating by reducing oxygen levels below what is needed for direct germination (39); sporangia of $P$. infestans germinated when moved to an environment with sufficient oxygen. Therefore, it is possible that some sporangia and zoospores present on the surface of tubers located deep in the soil do not germinate directly and infect tubers due to anaerobic conditions. When these tubers are exposed to air during lifting, soil cracking, or erosion, sufficient oxygen levels may become available for germination to take place, providing the spores remained viable and the environmental conditions are conducive for germination.

Zoospores of $P$. infestans may not innately move down into the soil. Zoospores of many Phytophthora spp., such as $P$. cactorum, $P$. palmivora, and $P$. nicotianae, are negatively geotaxic and have a tendency to swim upward and stay near the water surface (7). There is evidence for 
negative geotaxism of zoospores in $P$. infestans (8). If zoospores of $P$. infestans are negatively geotaxic, they would swim toward the surface of water and would be less likely to move down into the soil. Zoospores also have a tendency to encyst on impact with objects (8). Zoospores may experience a greater number of impacts as they move to greater soil depths, decreasing the likelihood of further active movement through soil.

The incidence of infection of tubers at the soil surface was $54 \%$ (293 infected of 542) when all surface tubers were combined over all experiments. Sunburned or green tubers harvested from fields with late blight during the growing season are high-risk tubers due to their surface location, but can be recognized easily by growers for removal. The buds of green tubers are susceptible to infection (unpublished data). Therefore, it may be wise for growers to sort out these high-risk tubers before they are placed in storage facilities. This would minimize the risk of tuber rot and spoilage of other healthy tubers in storage. Green and sunburned tubers also commonly are discarded into cull piles, which adds to the importance of destroying cull piles as part of the regional control measures for late blight management (40).

Soil in the present studies was not saturated before application of spores of $P$. infestans to maximize the infiltration of spores through the soil profile. Infiltration rates are initially high in dry soil and then decline as the soil becomes saturated (46). The lightly wetted soil provided moisture for zoospores to maintain motility. Inoculum was applied to the soil at night when cooler temperatures prevailed, to maximize survival, activity, and infection by spores $(12,44,53)$. Temperatures during and after soil infestation were favorable (17) for disease development. Water potential read- ings (Tables 1 and 2) indicated that the soil was at or near saturation, which is important to create continuous water-filled channels to allow for spore movement (10).

Advantages to testing spore movement through soil under controlled conditions in the greenhouse, as done in this study, were that intact and lack of intact soil conditions allowed for the accurate assessment of soil traits that reduced or prevented tuber infection at different soil depths. In summary, the present study supports field studies $(30,31)$ that indicate that hilling can be an effective late blight management strategy as long as intact soil is present over the surface of the tubers. Tubers located deep in the soil are better protected from infection than surface or shallow tubers. Silt soils may provide complete protection to tubers as long as there is an intact soil layer during the entire growing season. Even with intact soil coverage, tuber infection is more likely in sandy soil. Water management is important in preventing soil erosion and cracking, which provide cavities for tuber infection. Volume of water added to the soil surface under conditions of this study did not significantly increase depth of tuber infection.

\section{ACKNOWLEDGMENTS}

We thank L. M. Carris and R. E. Thornton for their critical review of this article, and T. F. Cummings for technical assistance.

\section{LITERATURE CITED}

1. Andrivon, D. 1994. Dynamics of the survival and infectivity to potato tubers of sporangia of Phytophthora infestans in three different soils. Soil Biol. Biochem. 26:945-952.

2. Andrivon, D. 1994. Fate of Phytophthora infestans in a suppressive soil in relation to $\mathrm{pH}$. Soil Biol. Biochem. 26:953-956.

3. Andrivon, D. 1995. Inhibition by aluminum of mycelial growth and of sporangial production and germination in Phytophthora infestans. Eur. J. Plant Pathol. 101:527-533.

4. Barr, D. J. S., and Desaulniers, N. L. 1990.

Table 5. Incidence of tuber infection when potato tubers were buried in soil at three soil depths in greenhouse pots and a spore suspension containing zoospores and sporangia of Phytophthora infestans was applied to the soil surface, after which one of three water volumes was applied to the soil surface $(n=18 \text {; experiment } \mathrm{C})^{\mathrm{w}}$

\begin{tabular}{lcccc}
\hline & \multicolumn{3}{c}{ Soil depth $^{\mathbf{x}}$} & \\
\cline { 2 - 4 } Soil type & Surface & $\mathbf{5} \mathbf{~ c m}$ & $\mathbf{1 3} \mathbf{~ c m}$ & Total incidence (\%) $^{\mathbf{y}}$ \\
\hline Potting soil & $89 \mathrm{a}$ & $56 \mathrm{a}$ & $17 \mathrm{a}$ & $54 \mathrm{~A}$ \\
Quincy medium sand & $72 \mathrm{a}$ & $22 \mathrm{~b}$ & $0 \mathrm{a}$ & $31 \mathrm{~B}$ \\
Quincy loamy fine sand & $83 \mathrm{a}$ & $22 \mathrm{~b}$ & $6 \mathrm{a}$ & $37 \mathrm{~B}$ \\
Shano silt loam & $17 \mathrm{~b}$ & $0 \mathrm{~b}$ & $0 \mathrm{a}$ & $6 \mathrm{C}$ \\
Mean incidence $^{\mathrm{z}}$ & 65 & 25 & 6 & 32 \\
\hline
\end{tabular}

${ }^{\mathrm{w}}$ Soil was inoculated under greenhouse conditions with $5.0 \times 10^{4}$ sporangia/pot in $100 \mathrm{ml}$ of water and then with $8.13 \times 10^{5}$ sporangia/pot in $100 \mathrm{ml}$ water, $24 \mathrm{~h}$ later. Sporangia were chilled at $4^{\circ} \mathrm{C}$ for two hours to induce zoospore formation. Soil in pots was irrigated with 1, 2.5, and 4.5 liters of water after each application of inoculum to soil, which was equivalent to $1.04,2.6$, and $4.6 \mathrm{~cm}$ of rain or irrigation water, respectively.

$x$ There were no significant differences between water volumes in incidence of tuber infection so results were combined $(P<0.05)$. Lowercase letters within a row represent significant differences between soil depths for a given soil type and uppercase letters within the column represent significant differences between the soil types in percent total incidence. Significant differences for both upper- and lowercase letters were determined using a series of pairwise differences by tests of two proportions with an adjusted Bonferroni procedure $(P<0.05)$

y Percent incidence of tuber infection for all soil depths combined for a given soil type.

${ }^{\mathrm{z}}$ Mean incidence of tuber infection for all soil types at a given soil depth.
The flagellar apparatus in the Phytophthora in festans zoospore. Can. J. Bot. 68:2112-2118.

5. Boyd, A. E. 1953. Susceptibility of immature potato tubers to blight. Plant Pathol. 2:113 116.

6. Bruehl, G. W. 1987. Soilborne plant pathogens. Pages 1-17 in: Soilborne Plant Pathogens. G. W. Bruehl, ed. MacMillian Publishing Co., New York.

7. Cameron, J. N., and Carlile, M. J. 1977. Negative geotaxis of zoospores of the fungus Phytophthora. J. Gen. Microbiol. 98:599-602.

8. Carlile, M. J. 1983. Motility, taxis, and tropism in Phytophthora. Pages 95-107 in: Phytophthora: Its Biology, Taxonomy, Ecology, and Pathology. D. C. Erwin, S. BartnickiGarcia, and P. H. Tsao, eds. American Phytopathological Society, St. Paul, MN.

9. Census of Agriculture. 2002. National Agricultural Statistics Service, Washington, DC.

10. Cook, R. J., and Duniway, J. M. 1987. Water relations in the life-cycles of soilborne plant pathogens. Pages 119-139 in: Soilborne Plant Pathogens. G. W. Bruehl, ed. MacMillian Publishing Co., New York.

11. Cook, R. J., and Papendick, R. I. 1972. Influence of water potential of soils and plants on root disease. Annu. Rev. Phytopathol. 10:349374.

12. Crosier, W. 1934. Studies in the biology of Phytophthora infestans. (Mont.) de Bary. Pages 1-40 in: Memoir 155. Cornell University, Agricultural Experiment Station, Ithaca, NY.

13. Dubey, T. James. R. V., and Stevenson, W. R. 1997. Effect of fungicide on viability of Phytophthora infestans sporangia in soil. (Abstr.) Phytopathology 87:S26.

14. Dubey, T., James, R. V., and Stevenson, W. R. 1998. The effect of 15 fungicides on viability of Phytophthora infestans sporangia in soil. (Abstr.) Phytopathology 88:S23.

15. Dubey, T., James, R. V., and Stevenson, W. R. 1999. The effect of fungicides on germination of Phytophthora infestans zoospores in soil. (Abstr.) Phytopathology 89:S21.

16. Dubey, T., and Stevenson, W. R. 1996. Factors affecting the movement and viability of sporangia of Phytophthora infestans in soil. (Abstr.) Phytopathology 86:S61.

17. Erwin, D. C., and Ribeiro, O. K. 1996. Phytophthora diseases worldwide. American Phytopathological Society, St. Paul, MN.

18. Fehrmann, H. 1963. Untersuchungen Zur Pathogenese Der Durch Phytophthora infestans Hervorgerufenen Braunfaule Der Kartoffelknolle. Phytopathol. Z. 46:371-376.

19. Gentry, H. R. 1984. Soil survey of Grant county, Washington. United States Department of Agriculture, Soil Conservation Service, Washington, DC.

20. Glass, J. R., Johnson, K. B., and Powelson, M. L. 2001. Assessment of barriers to prevent the development of potato tuber blight caused by Phytophthora infestans. Plant Dis. 85:521-528.

21. Goodwin, S. B., Smart, C. D., Sandrock, R. W., Deahl, K. L., Punja, Z. K., and Fry, W. E. 1998. Genetic change within populations of Phytophthora infestans in the United States and Canada 1994 to 1996: role of migration and recombination. Phytopathology 88:939949.

22. Hirst, J. M., Stedman, O. J., Lacey, J., and Hide, G. A. 1965. The epidemiology of Phytophthora infestans. IV. Spraying trials, 1959 to 1963 , and the infection of tubers. Ann. Appl. Biol. 55:373-395

23. Hosmer, D. W., and Lemeshow, S. 2000. Applied Logistic Regression. John Wiley and Sons Inc., New York.

24. Inglis, D., Gundersen, B., Derie, M., and Corsini, D. 2000. Evaluation of potato germplasm for resistance to late blight. $\mathrm{B} \& \mathrm{C}$ Tests 16:PT67. 
25. Inglis, D. A., Johnson, D. A., Legard, D. E., Fry, W. E., and Hamm, P. B. 1996. Relative resistances of potato clones in response to new and old populations of Phytophthora infestans. Plant Dis. 80:575-578.

26. Johnson, D. A., Cummings, T. F., and Hamm, P. B. 2000. Cost of fungicides used to manage potato late blight in the Columbia Basin: 1996 to 1998 . Plant Dis. 84:399-402.

27. Johnson, D. A., Cummings, T. F., Hamm, P. B., Rowe, R. C., Miller, J. S., Thornton, R. E., and Sorensen, E. J. 1997. Potato late blight in the Columbia Basin: an economic analysis of the 1995 epidemic. Plant Dis. 81:103-106.

28. Jones, L. R., Giddings, N. J., and Lutman, B. F. 1912. Investigations of the potato fungus Phytophthora infestans. Vermont Agric. Exp. Stn. Bull. No. 168. Burlington Free Press Printing Company, Burlington, VT.

29. Kuehl, R. O. 2000. Design experiments: statistical principles of research design and analysis. Duxbury Thomson Learning, NY.

30. Lacey, J. 1965. The infectivity of soils containing Phytophthora infestans. Ann. Appl. Biol. 56:363-380.

31. Lacey, J. 1966. The distribution of healthy and blighted tubers in potato ridges. Eur. Potato J. 9:86-98.

32. Lacey, J. 1967. Susceptibility of potato tubers to infection by Phytophthora infestans. Ann. Appl. Biol. 59:257-264.

33. Lacey, J. 1967. The role of water in the spread of Phytophthora infestans in the potato crop. Ann. Appl. Biol. 59:245-255.

34. Lapwood, D. H. 1977. Factors affecting the field infection of potato tubers of different cul- tivars by blight (Phytophthora infestans). Ann. Appl. Biol. 85:23-42.

35. Leamer, R. W., and Lutz, J. F. 1940. Determination of pore-size distribution in soils. Soil Sci. 49:347-360.

36. Lenfesty, C. D. 1967. Soil survey of Adams county, Washington. United States Department of Agriculture, Soil Conservation Service, Washington, DC.

37. Marshall, T. J. Holmes, J. W., and Rose, C. W. 1996. Soil Physics, 3rd ed. Cambridge University Press, New York.

38. Miller, J. S., Cummings, T. F., Mikitzel, L. J., and Johnson, D. A. 2002. Influences of timing of harvest in relation to haulm killing and planting date on potato tuber rot caused by Phytophthora infestans. Plant Dis. 86:264-268.

39. Murphy, P. A. 1922. The bionomics of the conidia of Phytophthora infestans. Sci. Proc. R. Dublin Soc. 16:442-466.

40. Murphy, P. A., and McKay, R. 1925. Further experiments on the sources and development of blight infection in potato tubers. J. Dep. Lds. Agric. Dublin 25:10-21.

41. Porter, L. P., Johnson, D. J., and Cummings, T. F. 1999. Tuber resistance/susceptibility of new potato cultivars to late blight. Spud Topics $44: 2$.

42. Rasmussen, J. J. 1971. Soil survey of Benton County area, Washington. United States Department of Agriculture, Soil Conservation Service, Washington, DC.

43. Ryan, T. P. 1996. Modern regression methods. John Wiley and Sons, New York.

44. Sato, N. 1979. Effect of soil temperature on the field infection of potato tubers by Phy- tophthora infestans. Phytopathology 69:989993.

45. Sato, N. 1980. Sources of inoculum and sites of infection of potato tubers by Phytophthora infestans in soil. Ann. Phytopathol. Soc. Jpn. 46:231-240.

46. Scott, H. D. 2000. Soil physics: Agricultural and Environmental Applications. Iowa State University Press, Ames.

47. Soil survey (SSURGO) database for Adams County, Washington. 2004. United States Department of Agriculture, National Resources Conservation Service, Fort Worth, TX.

48. Soil survey (SSURGO) database for Benton County, Washington. 2004. United States Department of Agriculture, National Resources Conservation Service, Fort Worth, TX.

49. Soil survey (SSURGO) database for Grant County, Washington. 2004. United States Department of Agriculture, National Resources Conservation Service, Fort Worth, TX.

50. Stewart, H. E., McCalmont, D. C., and Wastie, R. L. 1983. The effect of harvest date and the interval between harvest and inoculation on the assessment of the resistance of potato tubers to late blight. Potato Res. 26:101-107.

51. Stolzy, L. H., Letey, J., Klotz, L. J., and Labanauskas, C. K. 1965. Water and aeration as factors in root decay of Citrus sinensis. Phytopathology 55:270-275.

52. Uppal, B. N. 1926. Relation of oxygen to spore germination in some species of the Peronosporales. Phytopathology 16:285-292.

53. Zan, K. 1962. Activity of Phytophthora infestans in soil in relation to tuber infection. Trans. Br. Mycol. Soc. 45:205-221. 